\section{Morphological and Physiological Characteristics of Leea coccinia and Leea rubra in Response to Light Flux}

\author{
J.M. Sarracino, R. Merrit ${ }^{2}$, and C.K. Chin ${ }^{2}$ \\ Department of Horticulture, Rutgers University, Cook College, New \\ Brunswick, NJ 08903
}

Additional index words. Ficus benjamina, acclimatization, chlorophyll, anthocyanins

Abstract. Two foliage plant species, Leea coccinia $\mathbf{L}$. and Leea rubra $\mathbf{L}$., were evaluated for survival and for morphological and physiological changes in response to low light flux. Both species of Leea survived in light as low as that survived by Ficus benjamina L. Following 124 days under simulated interior lighting conditions of 5.7, 2.6 , or $0.70 \mathrm{~mol}^{-2} \cdot \mathrm{day}^{-1}$, L. coccinia, L. rubra, and $F$. benjamina plants grown in $92 \%$ shade had lower total fresh/dry weight, smaller leaf area, and thinner leaves than plants grown in full sun. After 124 days, plants of all three species in 92\% shade were shorter, narrower, and had fewer growing points than plants in full sun. After 124 days, plants of $L$. coccinia grown in $92 \%$ shade contained more total chlorophyll, and more chlorophyll a and $b$, and they had a lower chlorophyll a : b ratio than plants from full sun. Anthocyanin content in L. rubra plants grown in $92 \%$ shade was lower than that of plants grown in full sun. Plants of $F$. benjamina grown in $92 \%$ shade contained more total chlorophyll and more chlorophyll a and $b$ than plants grown in full sun.

Many plants grown successfully indoors under low light conditions include small herbaceous plants such as ferns, little leaf schefflera (Schefflera arbicola L.), and Aglaonema spp. (Larson, 1979). Large plants are appropriate in many interior locations, but the availability of large plant selections is limited largely to Ficus benjamina trees (Collard et al., 1977; Conover and Poole, 1975; Fails et al., 1982a). However, Leea coccinia and $L$. rubra may partially fill the need for diversity in large interior plants. These plants are multi-stemmed, have bi- and tri-pinnately compound leaves and produce large, pink compound umbel type inflorescenes. Both are native to the Burma/India region and are grown in the islands of the Caribbean and Hawaii under a range of light flux, from full sun to dense shade (Liberty Hyde Bailey Hortorium, 1977; Ko et al., 1981).

Plant growth in interior environments may be limited by temperature and humidity, but light is often the most limiting factor (Collard et al., 1977; Conover and Poole, 1975; Fails et al., 1982b; Larson, 1979). Interior lighting levels vary considerably and are often low. Measurements in offices ranged from 0.18 to $1.4 \mathrm{~mol} \cdot \mathrm{m}^{-2} \cdot \mathrm{day}^{-1}$ (2 to 16

Received for publication 30 Aug. 1991. Accepted for publication 27 Dec. 1991. New Jersey Agricultural Experiment Station, Publication no. D03130-5-92, supported by state funds. We acknowledge and thank Douglas Eberhardt for his assistance in the statistical analyses. The cost of publishing this paper was defrayed in part by the payment of page charges. Under postal regulations, this paper therefore must be hereby marked advertisement solely to indicate this fact.

'Technology Licensing Assistant, Rutgers Univ., New Jersey Agricultural Experiment Station, 377 Hoes Lane, Piscataway, NJ 08855. ${ }^{2}$ Professor. days.

${ }^{2}$ Mean of four plants. Six plants of each species were selected. and can adapt rapidly from high light conditions to dim interior lighting may be suitable as interior plants.

Conklin (1970) first reported on the value of shading and a reduced watering schedule to acclimatize foliage plants before placement in building interiors. Conover and Poole (1975) demonstrated that plants of $F$. benjamina and Brassaia actinophylla L. held at reduced light levels (> 40\% shade) for as little as 5 weeks were of a higher grade and quality than plants that had not been under reduced light. Plants of $F$. benjamina acclimatized to reduced light conditions were taller and had larger leaves but a smaller total leaf area, fewer and thinner leaves, a thinner trunk, lower total carbohydrate content, and lower total fresh and dry weights than plants grown in full sun (Conover and Poole, 1977; Conover et al., 1982; Fails et al., 1982a, 1982b; Johnson et al., 1982; Milks et al., 1979). Also, their foliage was darker, glossier, and higher in total chlorophylls $a$ and $b$ than foliage produced under high light conditions (Collard et al., 1977; Conover and Poole, 1977; Fails et al., 1982a; Johnson et al., 1982; Joiner et al., 1980).

The objective of this study was to determine the ability of $L$. coccinia and $L$. rubra to adjust to simulated interior lighting conditions as compared with $F$. benjamina.

Leaf/bud cuttings of $L$. coccinia were

Table 1. Characteristics ${ }^{2}$ of Leea coccinia grown under four light levels in the greenhouse for 124

\begin{tabular}{|c|c|c|c|c|c|c|}
\hline \multirow[b]{2}{*}{$\begin{array}{l}\text { Measurement } \\
\text { day }\end{array}$} & \multirow{2}{*}{$\begin{array}{l}\text { Shade } \\
\text { levely } \\
(\%)\end{array}$} & \multicolumn{2}{|c|}{ Plant } & \multicolumn{2}{|c|}{ Leaf } & \multirow{2}{*}{$\begin{array}{c}\text { Growing } \\
\text { points } \\
\text { (no.) }\end{array}$} \\
\hline & & $\begin{array}{c}\mathrm{Ht} \\
(\mathrm{cm})\end{array}$ & $\begin{array}{l}\text { Width } \\
(\mathrm{cm})\end{array}$ & $\begin{array}{l}\text { Count } \\
\text { (no.) }\end{array}$ & $\begin{array}{c}\text { Thickness } \\
\text { (mm) }\end{array}$ & \\
\hline \multirow[t]{4}{*}{34} & 0 & 31.4 & 82.3 & 10 & 0.25 & 3.3 \\
\hline & 32 & 29.1 & 87.0 & 11 & 0.22 & 3.5 \\
\hline & 63 & 26.8 & 84.8 & 10 & 0.23 & 3.3 \\
\hline & 92 & 29.9 & 90.4 & 10 & 0.21 & 2.0 \\
\hline \multicolumn{7}{|l|}{ Significance } \\
\hline Shade & & NS & NS & NS & $* *$ & NS \\
\hline Linear & & NS & NS & NS & $* * *$ & NS \\
\hline Quadratic & & NS & NS & NS & $*$ & NS \\
\hline \multirow[t]{4}{*}{61} & 0 & 32.5 & 90.9 & 13 & 0.21 & 3.0 \\
\hline & 32 & 29.9 & 93.0 & 13 & 0.22 & 2.5 \\
\hline & 63 & 26.6 & 94.9 & 15 & 0.19 & 1.8 \\
\hline & 92 & 30.0 & 92.5 & 11 & 0.17 & 2.0 \\
\hline \multicolumn{7}{|l|}{ Significance } \\
\hline Shade & & NS & NS & NS & $* * *$ & NS \\
\hline Linear & & NS & NS & NS & $* * *$ & NS \\
\hline Quadratic & & NS & NS & NS & $* *$ & NS \\
\hline \multirow[t]{4}{*}{95} & 0 & 33.6 & 97.0 & 13 & 0.22 & 3.8 \\
\hline & 32 & 30.5 & 91.8 & 15 & 0.21 & 2.5 \\
\hline & 63 & 27.4 & 98.5 & 15 & 0.18 & 2.8 \\
\hline & 92 & 30.3 & 92.0 & 11 & 0.17 & 1.8 \\
\hline \multicolumn{7}{|l|}{ Significance } \\
\hline Shade & & * & NS & NS & *** & NS \\
\hline Linear & & * & NS & NS & $* * *$ & NS \\
\hline Quadratic & & $*$ & NS & NS & NS & NS \\
\hline \multirow[t]{4}{*}{124} & 0 & 35.4 & 96.0 & 17 & 0.22 & 3.8 \\
\hline & 32 & 34.5 & 96.0 & 17 & 0.21 & 2.5 \\
\hline & 63 & 31.5 & 99.8 & 18 & 0.19 & 2.3 \\
\hline & 92 & 30.6 & 93.0 & 13 & 0.17 & 2.8 \\
\hline \multicolumn{7}{|l|}{ Significance } \\
\hline Shade & & NS & NS & NS & $* *$ & NS \\
\hline Linear & & NS & NS & NS & $* *$ & NS \\
\hline Quadratic & & NS & NS & NS & NS & NS \\
\hline
\end{tabular}

$\mathrm{y} 0 \%=8.37,32 \%=5.67,63 \%=2.61$ and $92 \%=0.70 \mathrm{~mol} \cdot \mathrm{m}^{-2} \cdot \mathrm{day}^{-1}$.

NS,*,**,*** Not significant or significant at $P=0.05,0.01$, or 0.001 , respectively. 
Table 2. Characteristics ${ }^{2}$ of Leea rubra grown under four light leveis in the greenhouse for 124 days.

\begin{tabular}{|c|c|c|c|c|c|c|}
\hline \multirow[b]{2}{*}{$\begin{array}{l}\text { Measurement } \\
\text { day }\end{array}$} & \multirow{2}{*}{$\begin{array}{c}\text { Shade } \\
\text { levely } \\
(\%)\end{array}$} & \multicolumn{2}{|c|}{ Plant } & \multicolumn{2}{|c|}{ Leaf } & \multirow{2}{*}{$\begin{array}{c}\text { Growing } \\
\text { points } \\
\text { (no.) }\end{array}$} \\
\hline & & $\begin{array}{c}\mathrm{Ht} \\
(\mathrm{cm})\end{array}$ & $\begin{array}{l}\text { Width } \\
\text { (cm) }\end{array}$ & $\begin{array}{c}\text { Count } \\
\text { (no.) }\end{array}$ & $\begin{array}{l}\text { Thickness } \\
\text { (mm) }\end{array}$ & \\
\hline 34 & $\begin{array}{r}0 \\
32 \\
63 \\
92\end{array}$ & $\begin{array}{l}38.8 \\
33.6 \\
34.6 \\
34.2\end{array}$ & $\begin{array}{l}68 \\
61 \\
66 \\
65\end{array}$ & $\begin{array}{r}11 \\
9 \\
10 \\
8\end{array}$ & $\begin{array}{l}0.24 \\
0.22 \\
0.20 \\
0.17\end{array}$ & $\begin{array}{l}6.3 \\
4.5 \\
4.5 \\
2.5\end{array}$ \\
\hline \multicolumn{7}{|l|}{ Significance } \\
\hline Shade & & NS & NS & * & * & NS \\
\hline Linear & & NS & NS & $*$ & $* * *$ & NS \\
\hline Quadratic & & NS & NS & NS & NS & NS \\
\hline \multirow[t]{4}{*}{61} & 0 & 38.1 & 70 & 11 & 0.21 & 3.8 \\
\hline & 32 & 33.9 & 67 & 10 & 0.20 & 4.8 \\
\hline & 63 & 35.6 & 67 & 11 & 0.19 & 4.5 \\
\hline & 92 & 34.9 & 60 & 7 & 0.18 & 3.8 \\
\hline \multicolumn{7}{|l|}{ Significance } \\
\hline Shade & & NS & NS & NS & $*$ & NS \\
\hline Linear & & NS & NS & NS & $* *$ & NS \\
\hline Quadratic & & NS & NS & NS & NS & NS \\
\hline 95 & 0 & 38.9 & 71 & 18 & 0.20 & 3.3 \\
\hline & 32 & 33.9 & 70 & 17 & 0.19 & 4.0 \\
\hline & 63 & 34.9 & 70 & 16 & 0.18 & 4.3 \\
\hline & 92 & 24.9 & 59 & 9 & 0.18 & 3.3 \\
\hline \multicolumn{7}{|l|}{ Significance } \\
\hline Shade & & NS & $*$ & $* * *$ & NS & NS \\
\hline Linear & & NS & $*$ & $* * *$ & NS & NS \\
\hline Quadratic & & NS & NS & $* *$ & NS & NS \\
\hline 124 & 0 & 37.8 & 74 & 20 & 0.20 & 3.0 \\
\hline & 32 & 34.3 & 71 & 20 & 0.21 & 5.0 \\
\hline & 63 & 36.1 & 71 & 19 & 0.18 & 4.3 \\
\hline & 92 & 35.8 & 59 & 11 & 0.17 & 2.5 \\
\hline \multicolumn{7}{|l|}{ Significance } \\
\hline Shade & & NS & $*$ & $* *$ & NS & NS \\
\hline Linear & & NS & $* *$ & **** & NS & NS \\
\hline Quadratic & & NS & NS & $* *$ & NS & NS \\
\hline
\end{tabular}

Mean of four plants.

$y_{0 \%}=8.37,32 \%=5.67,63 \%=2.61$ and $92 \%=0.70 \mathrm{~mol} \cdot \mathrm{m}^{-1} \cdot \mathrm{day}^{-1}$

NS,*,*****Not significant or significant at $P=0.05,0.01$ or 0.001 , respectively.

Table 3. Characteristics ${ }^{\mathrm{z}}$ of Ficus benjamina grown under four light levels in the greenhouse for 124 days.

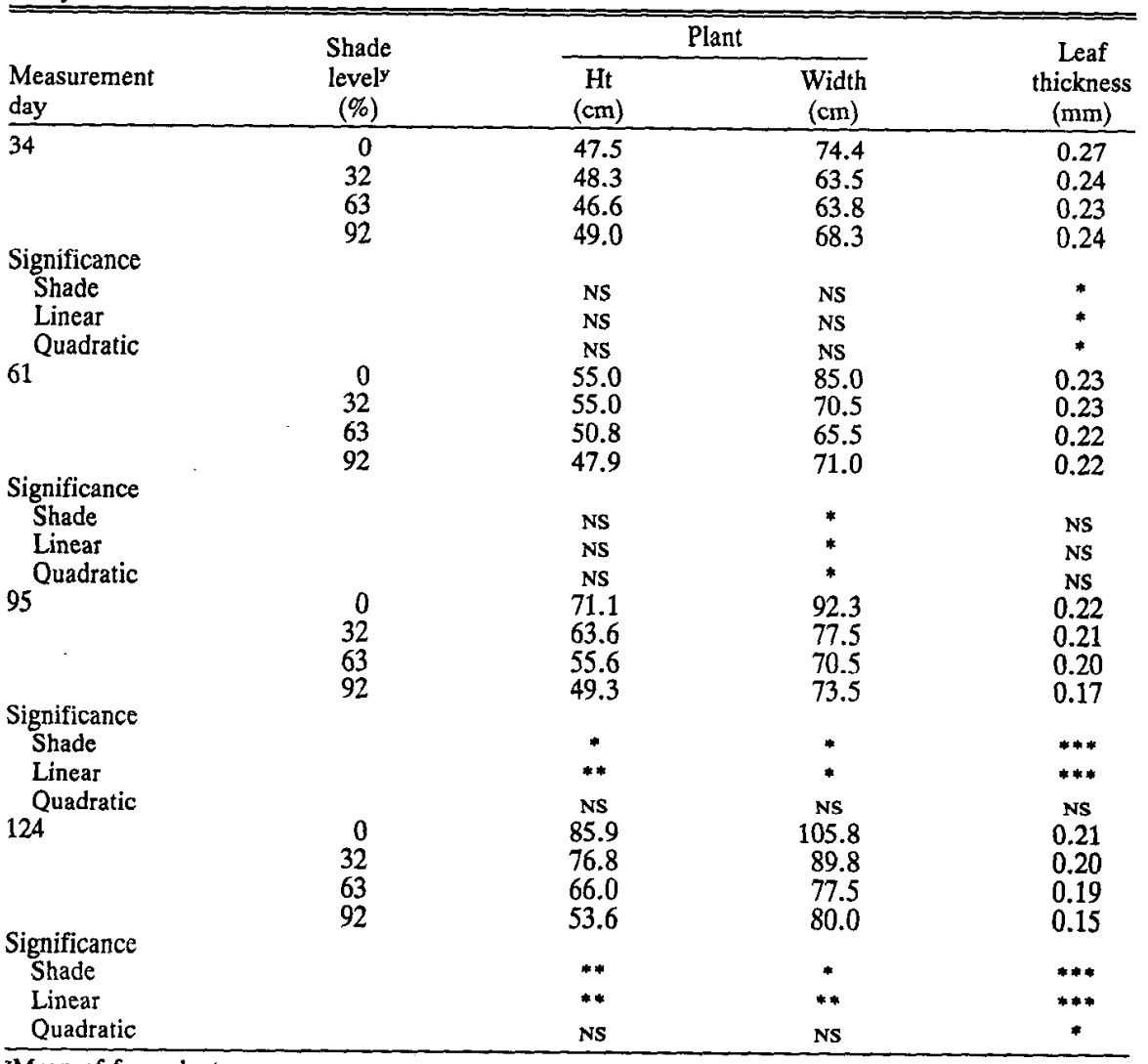

${ }^{2}$ Mean of four plants.

${ }^{y_{0}} \%=8.37,32 \%=5.67,63 \%=2.61$ and $92 \%=0.70 \mathrm{~mol} \cdot \mathrm{m}^{-2} \cdot$ day $^{-1}$.

Ns,***,***Not significant or significant at $P=0.05,0.01$ or 0.001 , respectively. rooted between 23 Feb. and 18 May 198.5 in 1 peat : 1 vermiculite $(\mathrm{v} / \mathrm{v})$. with bottom heat and mist. Cuttings of $F$. benjamina, consisting of three to five leaves, were treated with $0.3 \% 1 \mathrm{H}$ - indole-3-butanoic acid (IBA) and rooted between 16 Mar. and 22 June 1985 , in 2 peat : 1 perlite (v/v) with bottom heat and mist. Populations of L. rubra were produced from seeds obtained from $\mathrm{T}$. Lockhard, Aibonito, Puerto Rico. Seeds were germinated 3 Jan. 1985 in a flat of peat/ vermiculite mix using bottom heat at $28 \mathrm{C}$. All cuttings/seedlings were repotted twice between the propagation date and 6 July 1985 resulting in $\approx 210,280$, and 350 plants of $L$. coccinia, F. benjamina, and L. rubra, respectively, potted into 3-liter plastic containers. All plants were fertilized using $15 \mathrm{~N}$ $15 \mathrm{P}-15 \mathrm{k}$ water-soluble fertilizer at $200 \mathrm{ppm}$ $\mathrm{N}$ every 2 weeks.

A $4 \times 4 \times 3 \times 2$ repeated measure, factorial experimental design [four photosynthetic photon flux (PPF) levels, four measurement dates, three species, two replicates] was arranged in a greenhouse on 23 Oct. 1985. PPF treatments were achieved by completely covering the treatment areas with $0 \%, 32 \%, 63 \%$, or $92 \%$ density black polypropylene shade cloth. Six plants of each species were matched for uniformity of plant height and width, leaf count, size, age, and orientation, canopy density, and, for $F$. benjamina, number of growing points and number and angle of the branches. Matched groups of six plants for each species were placed in each of the eight treatments. Light flux and temperature were recorded throughout the experimental period using 190 SB quantum sensors (LI-COR, Lincoln, Neb.) and copper-constantan thermocouples attached to a Cambell CR-7 data logger (Cambell Scientific, Logan, Utah).

Repeated physical measurements, including plant height and width, leaf thickness (millimeters), and, for $L$. coccinia and $L$. rubra, leaf count, were recorded 27 Nov. and 24 Dec. 1985, 27 Jan. and 25 Feb. 1986. Destructive measurements, recorded on three plants of each species for all treatments on 6 Mar. 1986, including total top, leaf, and stem fresh and dry weights and leaf areas. Leaf samples consisting of several mature leaves (leaflets for L. coccinia and L. rubra) from the upper canopy were taken for all species in all treatments on 25 Feb. 1986 for determination of chlorophyll in $L$. coccinia and $F$. benjamina and anthocyanins in $L$. rubra. The procedure for chlorophyll extraction was as described by Holden (1976) and Salas (1988). The procedure for anthocyanin extraction was as described by Fuleki and Frances (1968) and Salas (1988). Total anthocyanin content, expressed as nano moles per square centimeter idaein equivalents, were calculated using the extinction coefficient $\left(3.43 \times 10^{4}\right)$ for idaein (Siegelman and Hendricks, 1957). All data were analyzed using the General Linear Model method and regression analysis to test for linear and quadratic effects.

Repeated morphological measurements. Increased duration under shade did not in- 
Table 4. Growth response of Leea coccinia, L. rubra, and Ficus benjamina to four light levels after 135 days in the greenhouse.

\begin{tabular}{|c|c|c|c|c|c|c|c|c|c|c|}
\hline \multirow[b]{3}{*}{ Species } & \multirow{3}{*}{$\begin{array}{l}\text { Shade } \\
\text { level } \\
(\%)^{z}\end{array}$} & \multicolumn{9}{|c|}{ Growth characteristics } \\
\hline & & \multicolumn{4}{|c|}{ Fresh wt (g) } & \multicolumn{4}{|c|}{ Dry wt (g) } & \multirow{2}{*}{$\begin{array}{c}\text { Total } \\
\text { leaf } \\
\text { area } \\
\left(\mathrm{cm}^{2}\right)\end{array}$} \\
\hline & & Total & Leaf & Rachis & Stem & Total & Leaf & Rachis & Stem & \\
\hline \multirow[t]{4}{*}{$\overline{\text { Leea coccinia }}$} & 0 & 433 & 238 & 113 & 82 & 140 & 83 & 30 & 27 & 9,610 \\
\hline & 32 & 395 & 216 & 105 & 75 & 120 & 70 & 27 & 23 & 8,870 \\
\hline & 63 & 436 & 266 & 99 & 71 & 122 & 83 & 22 & 17 & 11,700 \\
\hline & 92 & 245 & 148 & 63 & 34 & 53 & 36 & 11 & 7 & 6,880 \\
\hline \multicolumn{11}{|l|}{ Significance } \\
\hline Shade & & $* *$ & $*$ & $*$ & $* *$ & ** & $* *$ & $* *$ & $* *$ & NS \\
\hline Linear & & $* *$ & $*$ & $* *$ & $* *$ & $* *$ & $* *$ & $* *$ & $* *$ & NS \\
\hline Ouadratic & & NS & NS & NS & $* *$ & * & NS & $*$ & $* *$ & NS \\
\hline \multirow[t]{4}{*}{ Leea rubra } & 0 & 240 & 117 & 61 & 67 & 61 & 31 & 13 & 17 & 5,020 \\
\hline & 32 & 180 & 96 & 50 & 51 & 44 & 22 & 9 & 13 & 4,220 \\
\hline & 63 & 175 & 87 & 44 & 43 & 36 & 19 & 7 & 10 & 3,390 \\
\hline & 92 & 79 & 39 & 22 & 19 & 12 & 7 & 2 & 3 & 2,070 \\
\hline \multicolumn{11}{|l|}{ Significance } \\
\hline Shade & & $* *$ & ** & ** & ** & $* *$ & $* *$ & $* *$ & $*$ & * \\
\hline Linear & & ** & ** & $* *$ & $* *$ & $* *$ & $* *$ & $* *$ & $* *$ & $* *$ \\
\hline Quadratic & & NS & NS & NS & NS & NS & NS & NS & NS & NS \\
\hline \multirow[t]{4}{*}{ Ficus benjamina } & 0 & 282 & 136 & $\mathrm{NA}^{y}$ & 146 & 94 & 44 & NA & 52 & 5,470 \\
\hline & 32 & 222 & 96 & NA & 113 & 82 & 32 & NA & 46 & 3,750 \\
\hline & 63 & 163 & 89 & NA & 74 & 51 & 26 & NA & 25 & 3,650 \\
\hline & 92 & 114 & 64 & NA & 50 & 34 & 18 & NA & 16 & 2,900 \\
\hline \multicolumn{11}{|l|}{ Significance } \\
\hline Shade & & $* *$ & $* *$ & NA & ** & ** & ** & NA & $* *$ & ** \\
\hline Linear & & $* *$ & ** & NA & $* *$ & ** & ** & $\mathrm{NA}$ & ** & $* *$ \\
\hline Quadratic & & NS & NS & NA & NS & NS & NS & NA & NS & NS \\
\hline
\end{tabular}

${ }^{2} 0 \%=8.37,32 \%=5.67,63 \%=2.61$ and $92 \%=0.70 \mathrm{~mol}^{2} \cdot \mathrm{m}^{-2}$.day ${ }^{-1}$.

${ }^{\mathrm{N}} \mathrm{NA}=$ Not applicable.

NS,*,**Not significant or significant at $P=0.05$ or 0.01 , respectively.

Table 5. Mean chlorophyll concentrations for Leea coccinia and Ficus benjamina after 124 days grown under four light levels in the greenhouse.

\begin{tabular}{lccccc}
\hline \hline & \multirow{2}{*}{$\begin{array}{c}\text { Shade level } \\
(\%)^{2}\end{array}$} & \multicolumn{3}{c}{ Chlorophyll $\left(\mu \mathrm{g} \cdot \mathrm{cm}^{-2}\right)$} & Total \\
\cline { 3 - 6 } Species & 0 & $32.56^{\mathrm{y}}$ & 12.57 & 2.60 & 45.13 \\
\hline Leea coccinia & 32 & 38.82 & 15.71 & 2.49 & 54.53 \\
& 63 & 42.56 & 18.45 & 2.31 & 61.01 \\
& 92 & 51.04 & 24.40 & 2.10 & 75.44 \\
Significance & & $* *$ & $* *$ & $* *$ & $* *$ \\
Shade & & $* *$ & $* *$ & $* *$ & $*$ \\
Linear & & NS & NS & $* *$ & NS \\
Quadratic & 0 & 23.28 & 7.98 & 2.91 & 31.26 \\
Ficus benjamina & 32 & 36.76 & 12.79 & 2.87 & 49.54 \\
& 63 & 26.84 & 10.57 & 2.54 & 37.41 \\
& 92 & 38.45 & 15.02 & 2.57 & 53.47 \\
Significance & & $* *$ & $* *$ & $* *$ & $* *$ \\
Shade & & $* *$ & $* *$ & $* *$ & $* *$ \\
Linear & & NS & NS & NS & NS \\
Quadratic & & &
\end{tabular}

${ }^{20 \%}=8.37,32 \%=5.67,63 \%=2.61$ and $92 \%=0.70 \mathrm{~mol} \cdot \mathrm{m}^{-2} \cdot \mathrm{day}^{-1}$.

${ }^{y}$ Mean of four plants.

NS,*.**Not significant or significant at $P=0.05,0.01$, respectively.

crease the frequency of significant differences among the characteristics equally for all species, nor did it appear to increase the levels of significance in any criterion for all species. The number of growing points was not significantly different at any measurement date for any species (data not shown). Leaf thickness for plants of all species grown under full sun decreased marginally over the experiment period, probably due to the naturally low light levels during the fall. Changes that were significant, in general, displayed a linear trend; however, when changes were linear and quadratic, the linear effect was more significant.
(Codiaeum variegatum L.) grown under 950 $\mu \mathrm{mol} \cdot \mathrm{m}^{-2} \cdot \mathrm{s}^{-1}$ maximum photosynthetic photon flux density (PPFD), were taller and maintained more leaves than plants produced under $350 \mu \mathrm{mol} \cdot \mathrm{m}^{-2} \cdot \mathrm{s}^{-1}$ maximum PPFD.

Ficus benjamina. Plants grown in full sun were up to $38 \%$ taller and $27 \%$ wider with $29 \%$ thicker leaves than plants grown under any simulated interior lighting condition for 124 days. Differences in plant height and width, while not significant early in the experiment, were significant by day 95 and remained significant through day 124 (Table 3). Conover et al. (1982) also reported $F$. benjamina grown under $23 \mu \mathrm{mol} \cdot \mathrm{m}^{-2} \cdot \mathrm{s}^{-1} \mathrm{ir}$ radience to be taller than those grown under $13 \mu \mathrm{mol} \cdot \mathrm{m}^{-2} \cdot \mathrm{s}^{-1}$.

Leaf thickness differed significantly on three of four dates and at the highest level of significance $(P=0.001)$ with a predominately linear trend of decreasing thickness as a shade level increased (Table 3). Plants grown in full sun had $29 \%$ thicker leaves than plants grown in $92 \%$ shade. Other researchers have reported similar decreases in $F$. benjamina leaf thickness as light levels decrease (Conover and Poole, 1985; Fails et al., 1982a).

\section{Fresh and dry weights, leaf areas}

Leea coccinia. Fresh and dry weights of plant tops (total, leaves, rachis, and stems) decreased with increased shade level (Table 4). Leaf areas were similar for all treatments.

Leea rubra. Shade-grown plants were $25 \%$ to $67 \%$ lower in total fresh weight and $28 \%$ to $80 \%$ lower in total dry weight than those plants grown in full sun. Shade-grown plants had $16 \%$ to $59 \%$ less leaf area than those of sun-grown plants (Table 4). Similar observations were reported for sun- and shadegrown plants of some other interior plant species (Braswell et al., 1982; Conover and Poole, 1985; Conover et al., 1982).

Ficus benjamina. Plants grown under shade were $21 \%$ to $60 \%$ lower in total fresh weight, $13 \%$ to $64 \%$ lower in total dry weight, and had $47 \%$ less total leaf area than plants grown in full sun. These results are in agreement with those reported previously for $F$. benjamina (Fails et al., 1982a, 1982b; Johnson et al., 1982).

Chlorophyll concentration in leaves of $L$. coccinia increased linearly with increasing shading; total chlorophyll concentration for shade-grown plants was $17 \%$ to $40 \%$ higher than for sun-grown plants. Although both chlorophyll $a$ and $b$ levels were higher, the chlorophyll a : b ratio was lower. For $F$. benjamina, an increase in shading resulted in $16 \%$ to $42 \%$ higher total chlorophyll content, and, as in the case of $L$. coccinia, lower chlorophyll a : b ratio (Table 5). These results are similar to those for several other interior plant species as well as many shadetolerant forest species (Björkman and Holmgren, 1963; Braswell et al., 1982).

Anthocyanin concentration in L. rubra decreased linearly, by $8 \%$ to $43 \%$, with decreasing light intensity (Table 6). Similar observations of decreasing anthocyanin con- 
Table 6. Mean anthocyanin concentrations for Leea rubra after 124 days grown under four light levels in the greenhouse.

\begin{tabular}{lc}
\hline \hline $\begin{array}{l}\text { Shade level } \\
(\%)^{\mathrm{z}}\end{array}$ & $\begin{array}{c}\text { Anthocyanin } \\
\text { idaein equivalent }\end{array}$ \\
\hline 0 & $25.00^{\mathrm{y}}$ \\
32 & 19.17 \\
63 & 22.93 \\
92 & 14.36 \\
Significance & \\
Shade & $* *$ \\
Linear & $* *$ \\
Quadratic & NS \\
\hline
\end{tabular}

${ }^{2} 0 \%=8.37,32 \%=5.67,63 \%=2.61$ and $92 \%$ $=0.70 \mathrm{~mol}^{-2} \mathrm{~m}^{-2}$ day ${ }^{-1}$.

yMean of four plants.

NS.*.**Not significant or significant at $P=0.05$, 0.01 , respectively.

centration with decreasing light intensity have been reported for strawberry leaf disks (Creasy et al., 1965).

We found that $L$. coccinia and L. rubra, two species of large foliage plants, could survive direct transition from full sun to a relatively low light intensity that averaged $0.7 \mathrm{~mol} \cdot \mathrm{m}^{-2} \cdot$ day $^{-1}$, i.e. a normal office light intensity. The ability of these plant species to acclimate to this range of light intensity is comparable to that of the $F$. benjamina, a widely used large foliage plant. The ability of these plants to survive the low light intensity apparently was the result of the rapid morphological and physiological changes following the transfer from full sun to lower light intensity conditions. All three plant species exhibited reductions in leaf thickness, increases in chlorophyll concentrations, and reduction in chlorophyll $\mathrm{a}: \mathrm{b}$ ratios when shaded. These changes likely allow the plants to harvest light more efficiently than those growing in sunshine. Shaded plants did grow less, as expressed by fresh and dry weights and a reduced total leaf area in lower than normal light intensity. Nevertheless, they maintained their healthy appearance and ornamental qualities at the end of the experiment. Since rapid growth is not critical or even desirable for interior landscaping and since the plant specimens maintained good ornamental qualities, $L$. coccinia and $L$. rubra are appropriate landscape materials for relatively large office and home spaces.

\section{Literature Cited}

Bequette, B.L., T.M. Blessington, and J.A. Price 1985. Influence of lighting systematics on the interior performance of two croton cultivars. HortScience 20(5):927-929.

Björkman, O. and P. Holmgren. 1963. Adaptability of the photosynthetic apparatus to ligh intensity in ecotypes from exposed and shaded habitats. Physiol. Plant. 16:889-914.

Braswell, J.H., T.M. Blessington, and J.A. Price. 1982. Influence of production and postharvest light levels on the interior performance of two species of scheffleras. HortScience 17(1):48 50.

Collard, R.C., J.N. Joiner, C.A. Conover, and D.B. McConnell. 1977. Influence of shade and fertilizer on light compensation point of Ficus benjamina L. J. Amer. Soc. Hort. Sci. 102(4):447-449.

Conklin, E. 1970. A guide to interior planting. Everett Conklin, Montvale, N.J.

Conover, C.A. and R.T. Poole. 1975. Acclimatization of tropical trees for interior use. HortScience 10(6):600-601.

Conover, C.A. and R.T. Poole. 1977. Effects of cultural practices on acclimatization of Ficus benjamina L. J. Amer. Soc. Hort. Sci. 102(5):529-531.

Conover, C.A. and R.T. Poole. 1985. Acclimatization of indoor foliage plants. Annu. Rev. Plant Physiol. 36:119-154.

Conover, C.A., R.T. Poole, and T.A. Nell. 1982. Influence of intensity and duration of cool white fluorescent lighting and fertilizer on growth and quality of foliage plants. J. Amer. Soc. Hort. Sci. 107(5):817-822.

Creasy, L.L., E.C. Maxie, and C.O. Chichester.
1965. Anthocyanin production in strawberry leaf discs. Phytochemistry 4:517-521.

Fails, B.S., A.J. Lewis, and J.A. Barden. 1982a. Anatomy and morphology of sun- and shadegrown Ficus benjamina. J. Amer. Soc. Hort. Sci. 107(5):754-757.

Fails, B.S., A.J. Lewis, and J.A. Barden. 1982b. Light acclimatization potential of Ficus benjamina. J. Amer. Soc. Hort. Sci. 107(5):762766.

Fuleki, T. and F.J. Frances. 1968. Quantitative methods for anthocyanins. 1. extraction and determination of total anthocyanin in cranberries. J. Food Sci. 33:72-77.

Holden, M. 1976. Chlorophylls, p. 2-37. In: T.W. Goodwin (ed.). Chemistry and biochemistry of plant pigments. Academic, New York.

Johnson, C.R., T.A. Nell, S.E. Rosenbaum, and J.A. Lauritis. 1982. Influence of light intensity and drought stress on Ficus benjamina L. J. Amer. Soc. Hort. Sci. 107(2):252-255.

Joiner, J.N., C.R. Johnson, and J.K. Krantz. 1980. Effect of light and nitrogen and potassium levels on growth and light compensation point of Ficus benjamina L. J. Amer. Soc. Hort. Sci. 105(2):170-173.

Ko, W.H., J.Y. Uchida, R.K. Kunimoto, and M. Aragaki. 1981. Collar rot and leaf spot of leea caused by Calonectria crotalariae. Plant Dis. 65:621.

Larson, R. 1979. The tolerance of ornamental foliage plants to low light intensities. Swedish J. Agr. 9:169-172.

Liberty Hyde Bailey Hortorium. 1977. Hortus third: A concise dictionary of plants cultivated in the United States and Canada. Macmillan, New York. p. 643-644.

Milks, R.R., J.N. Joiner, L.A. Garard, C.A. Conover, and B. Tjia. 1979. Influence of acclimatization on carbohydrate production and translocation of Ficus benjamina L. J. Amer. Soc. Hort. Sci. 104(3):410-413.

Salas, S. 1988. Studies on the mode of action of butanedioic acid mono (2.2 dimethylhydrazide), PhD. Diss., Rutgers Univ. New Brunswick, N.J.

Siegelman, H.W. and S.B. Hendricks. 1957. Photocontrol of anthocyanin synthesis in apple skins. Plant Physiol. 33:185-190. 